\title{
First data on growth and nucleic acid and protein content of field-captured Mediterranean bluefin (Thunnus thynnus) and albacore (Thunnus alalunga) tuna larvae: a comparative study
}

\author{
ALBERTO GARCÍA ${ }^{1}$, DOLORES CORTÉS ${ }^{1}$, TEODORO RAMÍREZ ${ }^{1}$, \\ RAFIKA FEHRI-BEDOUI ${ }^{2}$, FRANCISCO ALEMANY ${ }^{3}$, JOSÉ M. RODRÍGUEZ ${ }^{4}$, \\ ÁNGEL CARPENA ${ }^{1}$ AND JUAN P. ÁLVAREZ ${ }^{1}$ \\ ${ }^{1}$ Instituto Español de Oceanografía, Aptdo. 285, 29640 Fuengirola, Málaga, Spain. E-mail: agarcia@ma.ieo.es \\ ${ }^{2}$ Unité de recherche de Biologie, Ecologie et de Parasitologie des Organismes Aquatiques, Département de Biologie, \\ Faculté des Sciences de Tunis, 2092 El Manar, Tunis, Tunisie. \\ ${ }^{3}$ Instituto Español de Oceanografía, Muelle Pelaires, Palma de Mallorca, Spain. \\ ${ }^{4}$ Instituto Español de Oceanografía, Gijón, Asturias, Spain.
}

\begin{abstract}
SUMMARY: The waters surrounding the Balearic archipelago are considered to be prime spawning habitats of the bluefin tuna (Thunnus thynnus) and other tuna species such as albacore (T. alalunga) in the Mediterranean. During the 2003 bluefin and albacore spawning season, a tuna larval survey (TUNIBAL 0703) was carried out to assess the distribution of bluefin larvae in relation to hydrographic mesoscale features. Tuna larvae were collected by means of surface plankton tows with a bongo gear with a quadrangular mouth measuring $1 \mathrm{~m}$ diagonally. The otolith microstructure of 157 and 71 field-captured larvae of Mediterranean bluefin and albacore, respectively, were analyzed to estimate the daily growth pattern. Furthermore, biochemical analysis to estimate DNA, RNA and protein content was done on another batch of 114 bluefin and 132 albacore larvae. The size range included pre-flexion to post-flexion larvae, from 2.8 to $8.6 \mathrm{~mm}$ in body length. bluefin and albacore larvae grew linearly in standard length $(0.35$ and $0.33 \mathrm{~mm} /$ day, respectively) and potentially with respect to dry weight. No significant differences between species were observed in the size-weight relationship, or in the allometric relationship of body size and weight to otolith radius. However, the relationship of DNA and RNA to body size and weight showed a significant difference between species. Bluefin tuna larvae showed a greater nucleic acid content than albacore larvae. Protein content showed no significant differences with respect to body length.
\end{abstract}

Keywords: bluefin tuna, albacore tuna, larvae, Mediterranean, growth, RNA/DNA, proteins.

RESUMEN: CRECIMIENTO Y CONTENIDO DE LARVAS DE ATÚN ROJO (THUNNUS THYNNUS) Y ATÚN BLANCO (THUNNUS ALALUNGA). - Las aguas de las Islas Baleares representan una de las zonas más importantes de puesta del atún rojo (Thunnus thynnus) y de otras especies asociadas, como el atún blanco albacore (T. alalunga). En julio del 2003, época de puesta del atún, se realizó la campaña TUNIBAL, con el fin de delimitar las zonas de puesta del atún rojo, así como su relación con el modelo de circulación en el área. Las larvas de atunes se muestrearon mediante arrastres superficiales con una red Bongo de boca cuadrangular ( $1 \mathrm{~m}$ en diagonal). Para el estudio del crecimiento diario, 157 larvas de atún rojo y 71 larvas de atún blanco fueron analizadas. Para el estudio de la condición larvaria (DNA, RNA y proteínas), 119 larvas de atún rojo y 138 larvas de atún blanco fueron analizadas. Se analizaron larvas desde estados de pre-flexión a post-flexión, desde 2.8 a 8.6 mm de longitud estándar. Las larvas de atún rojo y atún blanco crecen linealmente en longitud estándar $(0.35$ y $0.33 \mathrm{~mm} /$ día respectivamente) y potencialmente en peso seco. No se encontraron diferencias significativas en la relación talla-peso, o en la relación del radio del otolito con talla o peso. Sin embargo, la relación entre DNA y RNA con talla o peso mostró diferencias significativas entre especies, siendo el atún rojo el que mostró mayores contenidos en ácidos nucleicos. No obstante, el contenido en proteínas no mostró diferencias significativas con la talla entre especies.

Palabras clave: atún rojo, atún blanco, larvas, Mediterráneo, crecimiento, RNA/DNA, proteínas. 


\section{INTRODUCTION}

The high economic value of the North Atlantic bluefin tuna (BFT), (Thunnus thynnus, Linnaeus, 1758) has led the species to a major decline, particularly during the 1990s, possibly due to fishery overexploitation (Anon., 2003). This led the Spanish Institute of Oceanography (IEO) to carry out a yearly sampling programme (TUNIBAL) aimed at characterising the BFT spawning habitat off the Balearic Sea, historically known as an important tuna spawning area (Dicenta, 1975, 1977).

The Balearic archipelago, a transitional region between Atlantic and Mediterranean water masses, is one of the most important spawning grounds of the BFT. The encounter of two distinct water masses, the lighter inflowing Atlantic waters and the saltier southward Mediterranean water mass, is responsible for the formation of intense frontal structures and for the intense geostrophic circulation of water masses (Pinot et al., 1995; LópezJurado et al., 1995; Vélez-Belchí and Tintoré, 2001). This hydrographic scenario is not only suitable for spawning of BFT, but also of a number of apex fish species, among which frigate tuna (Auxis rochei, Risso 1810) and albacore (T. alalunga, Bonnaterre, 1788) are the most abundant. Other tuna species, such as Sarda sarda (Bloch, 1793), Euthynnus alleteratus (Rafinesque, 1810) and Katsuwonus pelamis (Linnaeus, 1758), have also been recorded among tuna larval species, as well as a species of the Xiphidae family, the swordfish (Xiphias gladius, Linnaeus, 1758) (García, IEO unpublished data).

Consequently, species of a different origin such as the Atlantic BFT may compete in their early life stages with other tuna species that show a greater Mediterranean affinity, acclimated to the Mediterranean environmental conditions, such as albacore (ALB) and frigate tunas.

The reproductive seasonality between BFT and ALB show some differences. While BFT spawns from June to mid-July (Padoa, 1956), ALB spawns from July to September, peaking in August (Padoa, 1956; Alemany, 1997). In 2003, the spawning grounds of each species were spatially differentiated and associated with particular Atlantic and Mediterranean water masses (García et al., 2003a). Each water mass corresponds to specific environmental and bio-physical characteristics. The differences in the predominant environmental conditions during the early life stages of these species and the great morphological resemblance throughout their development led us to carry out a comparative study between BFT and ALB, focusing on their larval growth and nutritional condition.

Larval daily growth and nutritional condition are highly influenced by surrounding environmental conditions at early life stages. The joint analyses of daily growth by otolith microstructure examination and the larval content of DNA, RNA and protein (PROT), together with their corresponding condition indices, are effective tools for probing environmental effects on larval mortality. Daily growth studies of BFT began with the work of Brothers et al. (1983), focusing on juvenile BFT. However, studies of this type on BFT larvae are quite limited. Many daily growth studies have focused on the validation of daily periodicity of increment deposition, by using cultured specimens (Itoh et al., 2000; Miyashita et al., 2001; Wexler et al., 2001), by using field-captured juveniles to analyse age and growth rates (Jenkins and Davis, 1990; La Mesa et al., 2005) or by performing chemical tagging and recapture experiments (Radke, 1983; Laurs et al., 1985; Wexler, 1993). Another study on Atlantic BFT refers to the chemical composition of their otoliths (Radke and Morales-Nin, 1989).

A review on biochemical analyses to estimate nucleic acid content or proteins at early life stages of tuna yields even less information. Most studies have used histological methods to track the nutritional status of tuna larvae (Margulies, 1993; Kaji et al., 1996, 1999). The only study in which nucleic acid and protein content was analysed refers to the species T. maccoyi (Carter et al., 1998), for which the differences of specific growth rates and nutritional status in farmed juveniles subject to diet variations were assessed. Biochemical indices in numerous studies have provided insight into the analysis of environmental forcing acting in the planktonic domain (Berdalet and Estrada, 1993), specifically addressing early life history of fish (Clemmesen et al., 1997; Chicharo et al., 2003).

The comparative study of the two tuna species presented in this paper was to examine differences in larval growth patterns despite their morphological resemblance throughout their larval development bearing in mind that they occupy differentiated environmental niches from the bio-physical standpoint. 


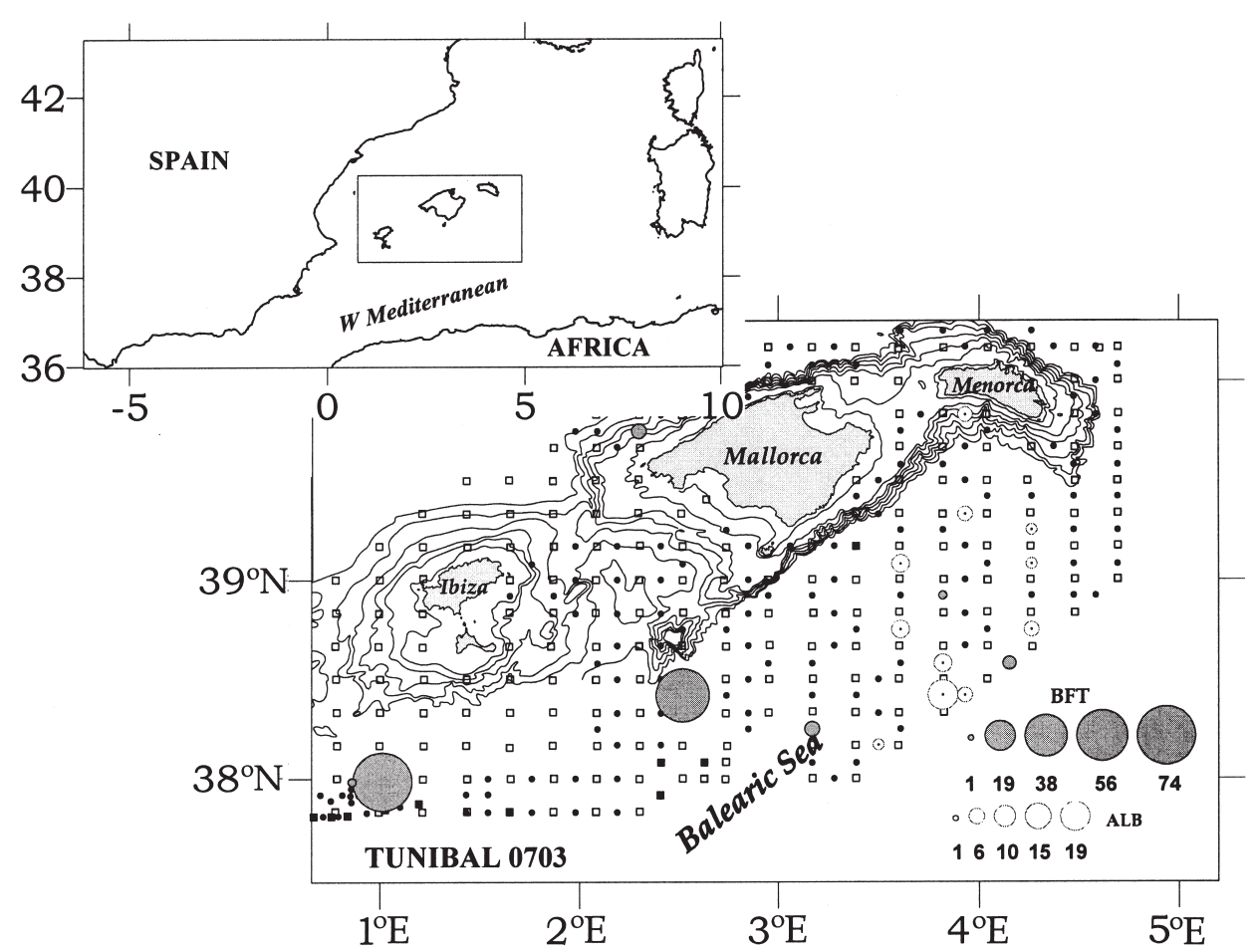

FIG. 1. - Station mapping of the TUNIBAL 0703 larval tuna survey. CTD stations are indicated with white squares and plankton hauls (Bongo 90) with dark dots. The number of larval tuna used for the analysis originate where major abundances of each species occurred. Proportionally sized white circles represent albacore larval samples while gray circles represent bluefin larval samples analysed in this study.

\section{MATERIALS AND METHODS}

\section{Field sampling}

The TUNIBAL survey was carried out on board the $R / V$ Cornide de Saavedra from July 4 to 30, 2003. A $10 \times 10 \mathrm{~nm}$ grid of hydrographic stations was set up for the hydrographic characterisation of the survey area (Fig. 1), with a total of 211 CTD (Seabird 25) casts over the survey area. At each hydrographic station, a vertical plankton tow to $70 \mathrm{~m}$ depth was performed with a CalVET plankton net whose mesh size was $55 \mathrm{~mm}$. Along the navigational path of the grid, a total of 236 sub-surface plankton tows, each one 10 miles apart, were carried out to collect larval tuna for daily growth and condition analyses. The number of tuna larvae used for the growth study of each species is shown in Figure 1. The plankton sampling gear used for this study was a squared mouth bongo frame measuring $1 \mathrm{~m}$ diagonally, equipped with a $500 \mathrm{~mm}$ mesh. The plankton tows lasted 10 minutes. Larval tuna were immediately sorted from glass trays, counted and dry frozen in liquid nitrogen.

The CalVET $55 \mathrm{~mm}$ mesh sample was sieved through 200 and $55 \mathrm{~mm}$ filters to separate the mesozooplankton fraction from the microzooplankton fraction. The filtered fraction was frozen to estimate its dry weight and to quantify protein and carbohydrate content through biochemical analysis.

\section{Laboratory procedures}

\section{Otolith preparation and analysis}

Tuna larvae of both species were selected from the stations where these were most abundant. The conserved tuna larvae were transferred from the liquid nitrogen containers to $\mathrm{a}-80^{\circ} \mathrm{C}$ freezer until the moment of otolith extraction. Randomly selected vials containing larvae (from 1-5) were removed from the freezer and thawed at room temperature. Larvae for otolith extraction and biochemical analysis were evenly distributed for each technique. The defrosted larvae were measured for standard length (SL) using NIH image analysis (US National Health Institute). To test differences between the relative body proportion between species, the maximum cephalic height $(\mathrm{CH})$, or head depth, and preanal length (PL) (snout to anus) were also measured. After measuring, the larvae were dehydrated in a dry freezer for 24 hours.

Larvae were then dry weighed on a precision balance with a precision of $1 \mu \mathrm{g}$. After dry weighing, larvae were re-hydrated with distilled water to 
facilitate otolith extraction. By means of a small fine scalpel, a cut on the dorsal side of the larva's head was performed to allow the otoliths to be extracted with fine needles. This procedure was done on a slide so that otoliths were moved away from the head. All the extracted otoliths were cleansed with a drop of distilled water and, once dry, fixed onto the slide with nail lacquer. The sagitta were only differentiated from the lapillus by light microscopy under $1000 \mathrm{x}$ magnitude due to their very small size difference in younger larvae, as observed by Wexler et al. (2001) in yellowfin tuna larvae (T. albacares).

Increments were counted along the largest axis of the sagitta using the OTO program designed by Andersen and Moksness (1988). Daily increment formation in the Pacific BFT was validated by Foreman (1996), as in the North Pacific albacore, $T$. alalunga (Laurs et al., 1985). The program runs on a Macintosh platform connected to a HEI digitiser and a high-resolution camera that projects the otolith on a video monitor. Sagittae with indistinct microstructures leading to conflicting age estimates were discarded.

The short life span of the sampled tuna larvae fitted well to linear models of size at age data. Otoliths showed petential growth. In the allometric relationships, such as otolith radius to larval size or larval size to weight, power models were more explicative.

ANCOVA was used to test the difference between somatic and otolith growth or allometric relationships between species. Previous to statistical analysis, some non-linear regression data were transformed to natural logarithms (Ln).

\section{Condition analysis by RNA, DNA and PROT content quantification}

Tuna larvae were homogenised by means of ultrasonic pulses $(2 \times 10 \mathrm{~s})$ at $0^{\circ} \mathrm{C}$ in $700 \mathrm{ml}$ of Trisbuffer (0.05 M Tris, 0.1 M NaCl, 0.01 M EDTA, pH 8.0) containing SDS $0.01 \%$ (final concentration). The homogenate was centrifuged at $6000 \mathrm{rpm}$ for 8 $\min$ at $4^{\circ} \mathrm{C}$. The DNA concentration in the supernatant was determined by fluorescence after incubation of one aliquot $(100 \mathrm{ml})$ with RNAase $0.02 \mathrm{mg}$ $\mathrm{ml}$ (final concentration) at $37^{\circ} \mathrm{C}$ for $30 \mathrm{~min}$. A second aliquot of supernatant $(100 \mathrm{ml})$ was transferred to another vial for total nucleic acid (RNA+DNA) determination. The fluorescent dye, ethidium bromide, was used for quantification of nucleic acids.
Fluorescence of samples was measured at exc: 360 nm, em: $590 \mathrm{~nm}$ against a blank. Calibration curves were made with DNA Type I from calf thymus and RNA Type III from baker's yeast (all from SIGMA). The standard curve slope ratio of RNA/DNA is 0.400-0.405 (mean=0.402; sd=0.0025). Detailed information on analytical procedures is provided in Belchier et al. (2004).

Protein content in the supernatant was determined in $200 \mathrm{ml}$ aliquots following the method of Lowry et al., (1951). Bovine serum albumin was used to make calibration curves.

The assignment of estimated ages to both tuna larval species subject to biochemical analysis was based on the frequency of increment counts within a determined larval size and weight range that had appeared in the aged larval populations. A proportional criterion in attributing increment counts to different size and weight categories was set.

\section{Microzooplankton analysis}

Microzooplankton analysis was determined after drying the samples in an electric oven to a constant weight at $60^{\circ} \mathrm{C}$ (Rao and Krupanidhi, 2001; Rao and Kumari, 2002). Samples were weighed to the nearest $0.1 \mu \mathrm{g}$. Subsequently, each sample was homogenised at $0^{\circ} \mathrm{C}$ in $1 \mathrm{ml}$ of Tris-buffer $(0.05 \mathrm{M}$ Tris, $0.1 \mathrm{M} \mathrm{NaCl}, 0.01 \mathrm{M}$ EDTA, adjusted to $\mathrm{pH} 8.0$ with $\mathrm{HCl})$ by means of ultrasonic pulses $(2 \times 10 \mathrm{~s})$. Afterwards, $15 \mu \mathrm{l}$ sodium $\cdot$ dodecylsulphate SDS $(0.7 \%)$ was added to the homogenate. The homogenate was centrifuged at $6000 \mathrm{rpm}$ for $8 \mathrm{~min}$ at $4^{\circ} \mathrm{C}$. An aliquot of $50 \mu \mathrm{l}$ from the supernatant was taken for protein analysis. Protein content was determined by the method of Lowry et al. (1951). The relative proportion of protein content in the total biomass of the microzooplankton, as measured by dry weight, was used as an index of relative quality of microzooplankton, as variations in biomass and biochemical constituents are influenced by the species composition of the sample (Rao and Krupanidhi, 2001; Rao and Kumari, 2002).

\section{RESULTS}

\section{Basic tuna larval sample statistics}

Most BFT larval samples were caught at two locations: a larval patch found south of Ibiza and a 


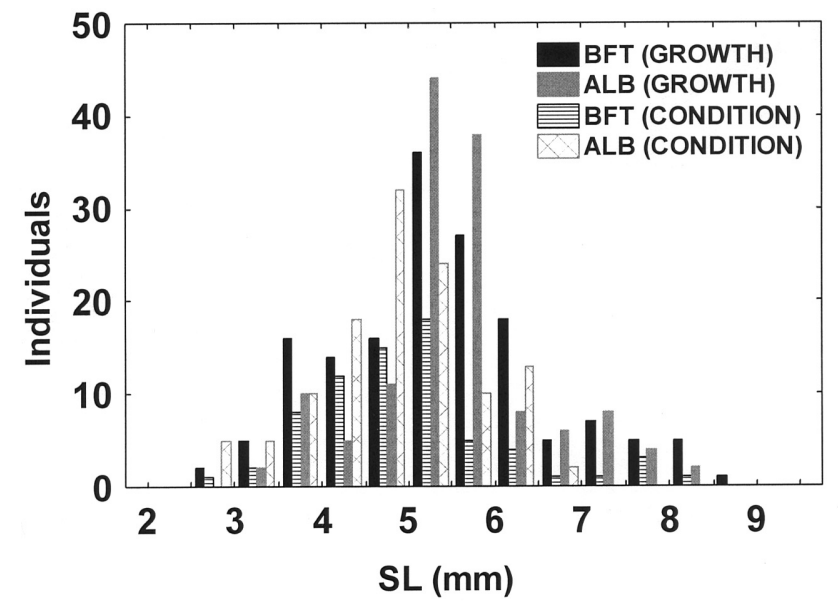

FIG. 2. - Size-frequency distribution of bluefin and albacore larval samples for the daily growth and condition analysis.

station south of the Mallorca channel (see Fig. 1). The ALB larvae originated from a series of stations along the southeastern part of the survey area. The stages of the tuna larvae varied from pre-flexion larvae to post-flexion larvae.

A total of 157 and 138 BFT larvae were analysed for the otolith microstructure and condition analysis, respectively. Their SL was 2.8-8.7 $\mathrm{mm}$ and 3.5-8.5 $\mathrm{mm}$, with a mean SL of $5.4 \mathrm{~mm}(\mathrm{sd}=1.223)$ and 5.5 $\mathrm{mm}(\mathrm{sd}=0.972)$, respectively. The total ALB larvae sampled for the daily growth study and condition analysis was 71 and 119, respectively. Their SL was 2.9-8.1 and 2.9-6.8 mm, with a mean SL of $5.00 \mathrm{~mm}$ $(\mathrm{sd}=1.072)$ and $4.8 \mathrm{~mm}(\mathrm{sd}=0.89)$, respectively. The size frequency of both species for both analyses showed normal distributions (Fig. 2).

The dry weight (DW) of BFT larvae was 0.042$2.868 \mathrm{mg}$ (mean $=0.615$; $\mathrm{sd}=0.566$ ) for the otolith study and $0.058-2.646 \mathrm{mg}$ (mean $=0.614 ; \mathrm{sd}=0.453$ ) for the condition analysis. The DW of ALB was $0.063-1.708 \mathrm{mg}$ (mean $=0.354$; $\mathrm{sd}=0.346$ ) for the otolith study and $0.034-1.901 \mathrm{mg}$ (mean=0.329; $\mathrm{sd}=0.269$ ) for the condition analysis.

\section{Morphometric analysis}

The morphological resemblance between BFT and ALB larvae is prominent. Under visual examination, the only distinguishing feature between the species lies in the absence of melanophores in ALB larvae along the trunk, while BFT has at least one melanophore on the dorsal side in the mid-section of the trunk. The allometric relationships of SL vs $\mathrm{CH}$ and PL are shown in Figure 3. The LnPL and $\mathrm{LnCH}$ did not show significant differences between the two

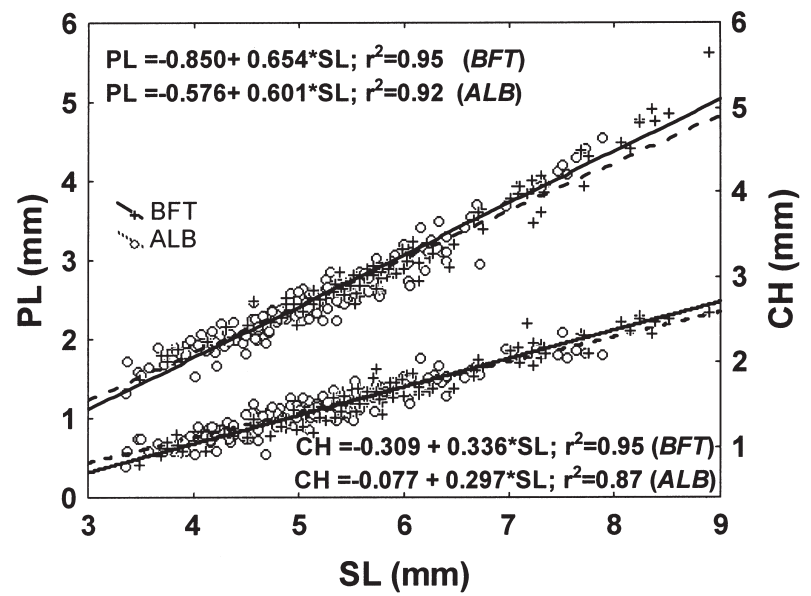

FIG. 3. - Preanal length (PL) and maximum head depth $(\mathrm{CH})$ vs SL relationship between BFT and ALB larvae.

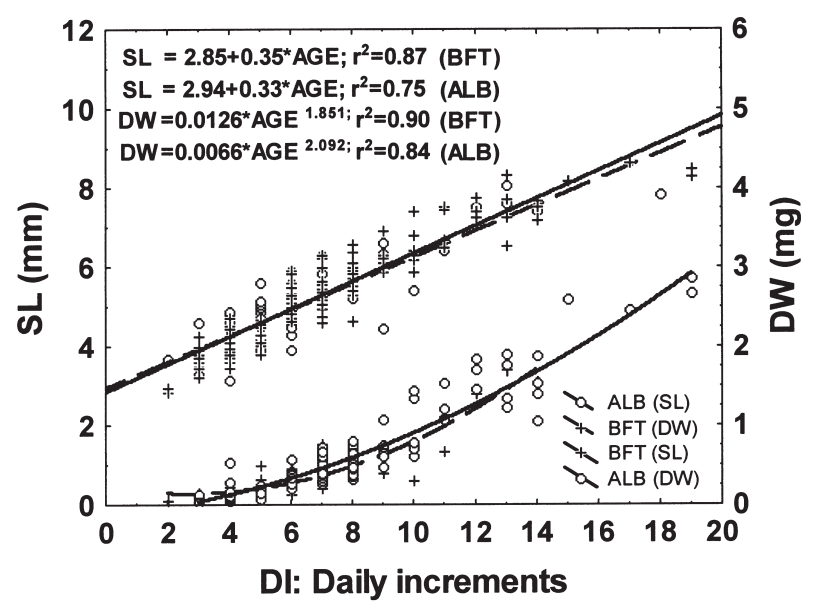

FIG. 4. - SL and DW vs age relationship of BFT and ALB larvae.

species, using LnSL as a covariate (ANCOVA, $\left.\mathrm{F}_{1,272}=2.3079, \mathrm{p}>0.05 ; \mathrm{F}_{1,272}=3.2158, \mathrm{p}>0.05\right)$.

\section{Somatic and otolith growth vs age}

The somatic growth of both species was linear in the case of SL vs age (Fig. 4). However, somatic growth, when referred to DW, showed potential growth with age (Fig. 4). The intercept of the sizeat-age model, which would represent size at hatch, as well as the slope representing the population growth rate, do not show great disparities between species. In the samples used for the growth study, ANCOVA did not show significant differences in LnSL and LnDW with LnAge as a covariate between species $\left(\mathrm{F}_{1,225}=0.05332, \quad \mathrm{p}>0.05\right.$; $\mathrm{F}_{1,225}=0.04024, \mathrm{p}>0.05$ respectively). Likewise, the larvae used for biochemical analysis did not show significant differences between species in LnSL and 
TABLE 1. - Somatic and otolith growth vs age, SL, DW of BFT and ALB larvae.

\begin{tabular}{|c|c|c|c|c|}
\hline Species & Somatic and otolith growth vs age & $\mathrm{r}^{2}$ & Somatic and otolith growth vs SL and vs DW & $\mathrm{r}^{2}$ \\
\hline \multirow[t]{3}{*}{ T. thynnus } & DNA $=0.09139 *$ age ${ }^{2.191}$ & 0.81 & $\mathrm{DW}=0.00764 * \mathrm{SL}^{3.791}$ & 0.92 \\
\hline & $\mathrm{RNA}=0.16579 *$ age $^{2.223}$ & 0.86 & $\mathrm{OR}=0.5124 * \mathrm{SL}^{2.268}$ & 0.89 \\
\hline & PROT $=0.89815 *$ age 2.539 & 0.85 & $\mathrm{OR}=0.0045 * \mathrm{DW}{ }^{1.485}$ & 0.92 \\
\hline \multirow[t]{3}{*}{ T. alalunga } & DNA $=0.08674 *$ age 2.177 & 0.75 & $\mathrm{DW}=0.00682 * \mathrm{SL}^{3.807}$ & 0.88 \\
\hline & $\mathrm{RNA}=0.16265^{*} \mathrm{age}^{2.120}$ & 0.74 & $\mathrm{OR}=0.7700 * \mathrm{SL}^{2.018}$ & 0.84 \\
\hline & PROT $=0.93396 *$ age $^{2.603}$ & 0.69 & $\mathrm{OR}=0.00213 * \mathrm{DW}{ }^{1.669}$ & 0.92 \\
\hline
\end{tabular}

LnDW with the estimated LnAge as a covariate $\left(\mathrm{F}_{1,267}=2.0688, \mathrm{p}>0.05 ; \mathrm{F}_{1,267}=1.5252, \mathrm{p}>0.05\right)$.

Somatic growth expressed by the amount of DNA, RNA and PROT content used as proxies of body size in the larval populations assigning estimated ages according to size and weight frequencies of the aged larval populations showed potential growth (see Table 1) in the whole size range of the sampled population. To avoid bias due to the greater number of larval sizes/weight of BFT, ANCOVA were limited to a maximum SL of $6 \mathrm{~mm}$. Within this range of SL, the amount of LnDNA and LnRNA between species showed significantly higher values in BFT larva (ANCOVA, $\mathrm{F}_{1,211}=4.826$; $\mathrm{p}<0.001$ : ANCOVA, $\left.\mathrm{F}_{1,211}=19.521 ; \mathrm{p}<0.001\right)$ with LnAge as a covariate. The comparison between LnPROT content did not show significant differences with estimated LnAge (ANCOVA, $\mathrm{F}_{1,191}=2.168 ; \mathrm{p}>0.05$ ).

With respect to otolith growth, power fits explain their growth with age, considering the average size of otolith core as the size at hatching for each species (6.8 $\mathrm{mm}$ and $7 \mathrm{~mm}$ for BFT and ALB, respectively (Fig. 5). The OR vs age relationship does not show significant differences between the two larval species (ANCOVA, $\mathrm{F}_{1,225}=2.285 ; \mathrm{p}>0.05$ ).

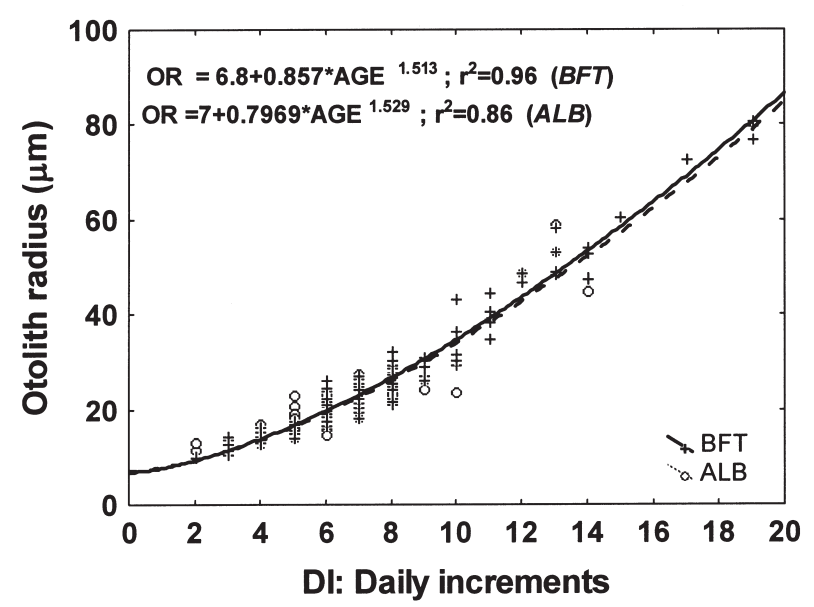

FIG. 5. - Otolith radius vs age relationship of BFT and ALB larvae.
Somatic and otolith growth vs size

The DW vs SL relationship followed power functions (Table 1) for the sampled population of both species. The linear relationship of LnDW vs LnSL of all the sampled larvae showed a significant difference between species (ANCOVA, $\mathrm{F}_{1,455}=$ 4.4725; $\mathrm{p}<0.05$ ) in favour of BFT. Since BFT larvae have a greater range of SL and DW, ANCOVA excluding SL above $6 \mathrm{~mm}$ maintained a significant difference in favour of BFT, although in the limit of
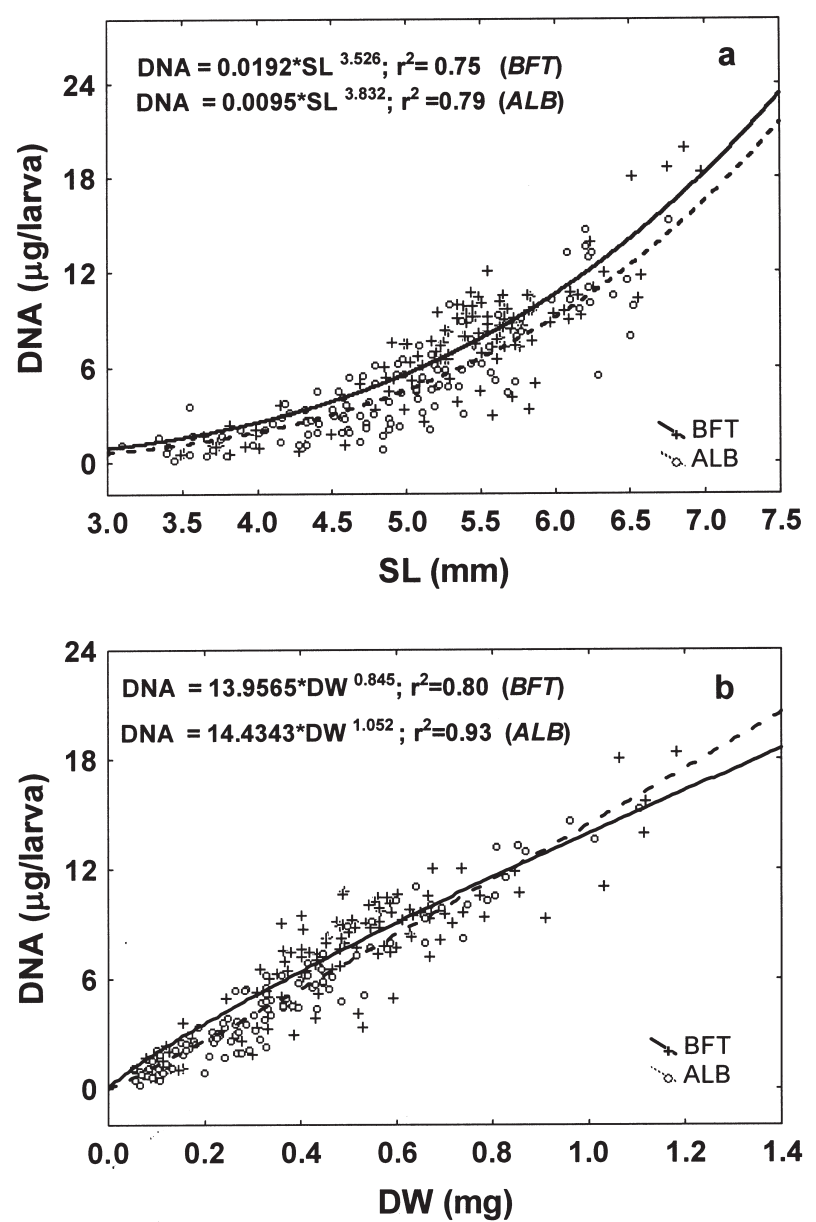

FIG. 6. - a) DNA content vs SL relationship of BFT and ALB larvae; b) DNA content vs DW relationship of BFT and ALB larvae. 

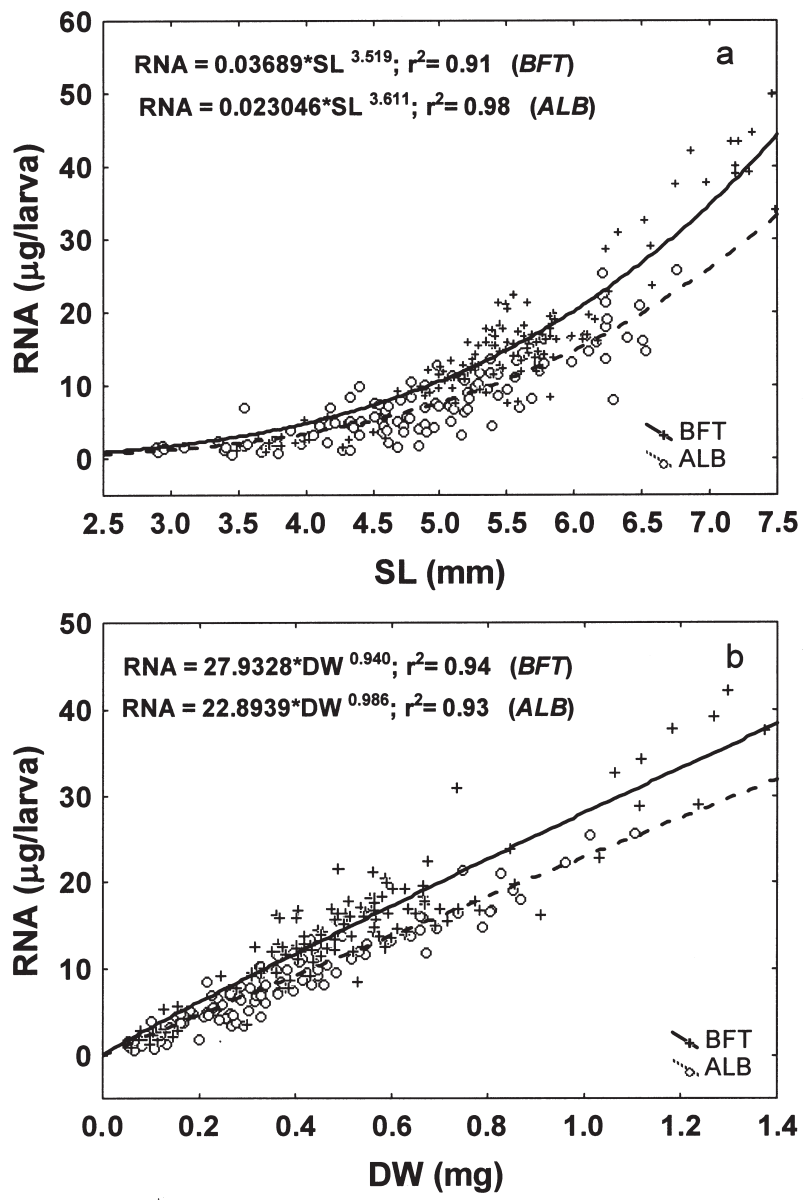

FIG. 7. - a) RNA content vs SL relationship of BFT and ALB larvae; b) RNA content vs DW relationship of BFT and ALB larvae.

significance level $\left(\mathrm{F}_{1,385}=3.9000, \mathrm{p}=0.049\right)$.

Larval otoliths showed potential growth with SL (Table 1). No significant differences between species were observed in LnSL vs LnOR (ANCO$\left.\mathrm{VA}, \mathrm{F}_{1,225}=4.5421 ; \mathrm{p}>0.05\right)$. Otoliths showed potential growth increase with DW. No differences were observed in LnDW vs LnOR (ANCOVA, $\mathrm{F}_{1,215}$ $=0.41958 ; \mathrm{p}>0.05$ ).

Concerning the biochemical parameters, DNA and RNA showed potential growth increase with SL and DW (Figs. 6a-b and 7a-b respectively). The relationship of LnDNA vs LnSL, excluding SL above $6 \mathrm{~mm}$, showed significantly higher DNA content in BFT (ANCOVA, $\left.\mathrm{F}_{1,211}=4.993 ; \mathrm{p}<0.05\right)$. The relationship of LnDNA vs LnDW showed significant differences when the range of DW was limited to a maximum DW of $0.8 \mathrm{mg}$, common to both species (ANCOVA, $\mathrm{F}_{1,222}=3.9714 \mathrm{p}<0.05$ ).

With respect to RNA content, a significantly higher increase of LnRNA with LnSL occurred in BFT $\left(\right.$ ANCOVA, $\left.\mathrm{F}_{1,211}=18.335 ; \mathrm{p}<0.001\right)$, exclud-
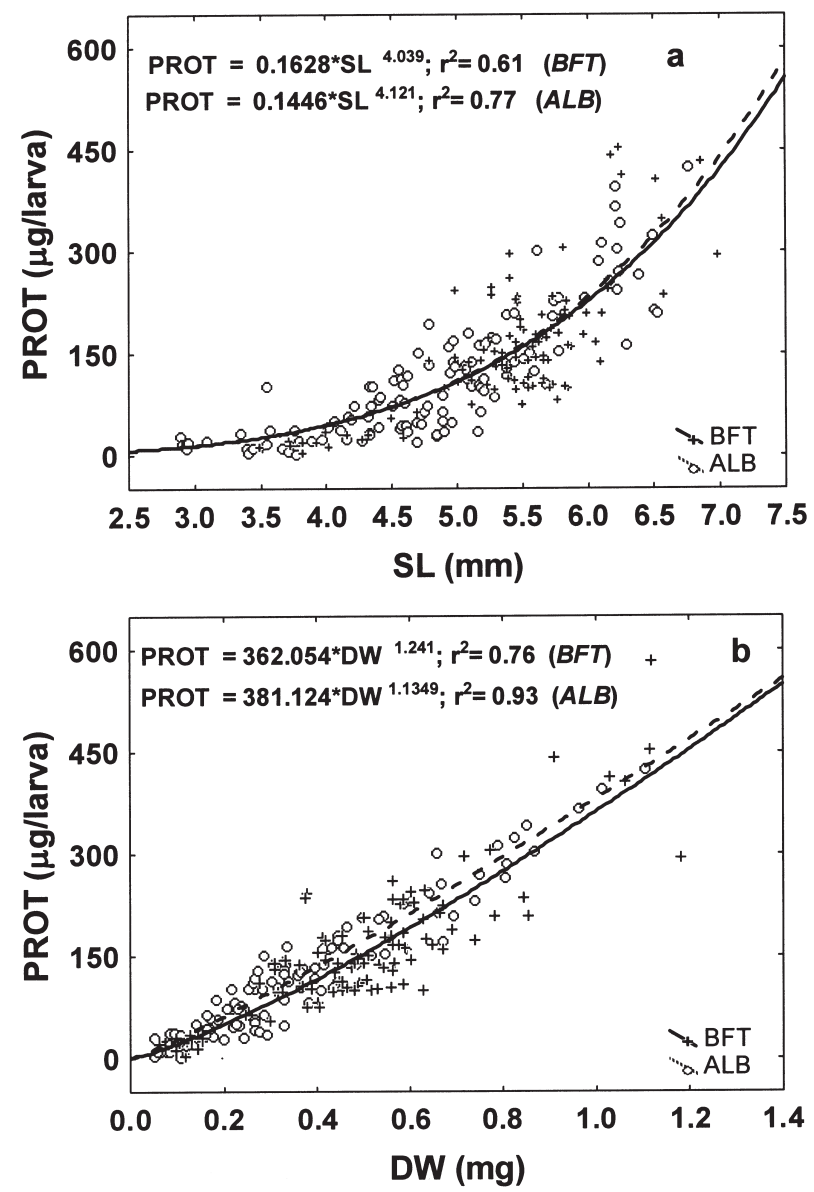

FIG. 8. - a) PROT content vs SL relationship of BFT and ALB larvae; b) PROT content vs DW relationship of BFT and ALB larvae.

ing SL higher than $6 \mathrm{~mm}$. Significantly higher LnRNA in BFT larvae was also observed in relation to $\mathrm{LnDW}$ (ANCOVA, $\mathrm{F}_{1,211}=28.782 ; \mathrm{p}<0.001$ ), excluding DW over $0.8 \mathrm{mg}$.

Lastly, PROT content fitted power functions in both species with SL and DW (Fig. 8a-b). The relationship of LnPROT with LnSL did not show significant differences between species (ANCOVA, $\mathrm{F}_{1,191}$ $=1.829 ; \mathrm{p}>0.05$ ), excluding SL over $6 \mathrm{~mm}$. However, the relationship of LnPROT vs LnDW for ALB showed significantly higher PROT content than for BFT (ANCOVA, $\mathrm{F}_{1,201}=8.4646 ; \mathrm{p}<0.01$ ) when the range of DW was limited to $0.8 \mathrm{mg}$. The relationship of PROT vs RNA is shown in Figure 9, denoting the fact that the ALB for the same RNA content yielded higher PROT.

\section{RNA/DNA ratios}

Figure 10 shows the distribution of RNA/DNA ratios of both species by increasing size categories. 


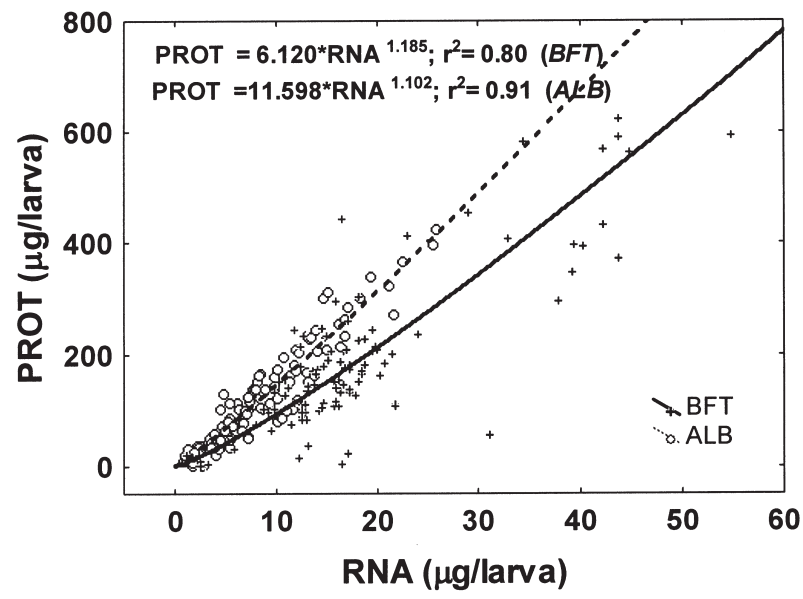

FIG. 9. - PROT content vs RNA content of BFT and ALB larvae.

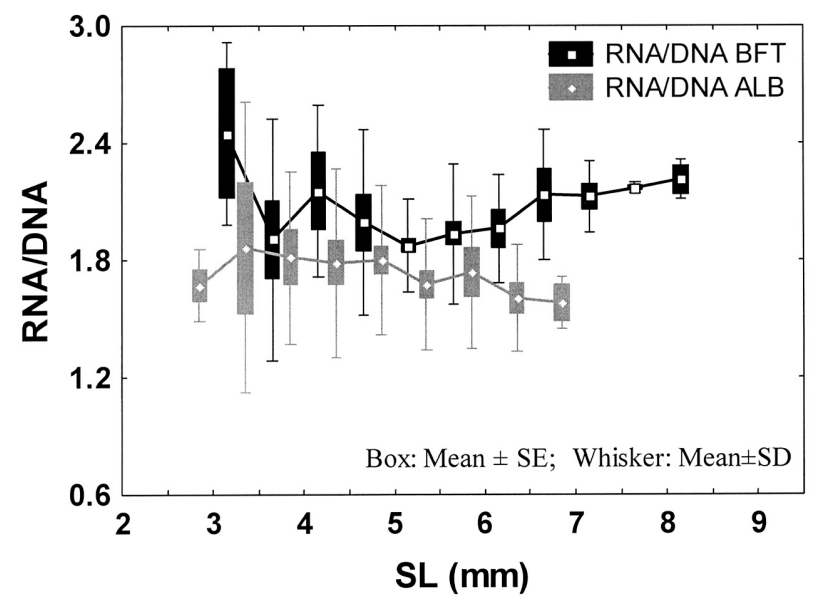

FIG. 10. - RNA/DNA ratios vs SL of BFT and ALB larvae.

The RNA/DNA ratios do not seem to follow any significant trend with size or weight.

The RNA/DNA ratios for BFT larvae varied from 0.88 to 3.27 (Mean=1.97; sd =0.35), while for ALB they varied from 1.00 to 3.18 (Mean $=1.74$; sd $=0.39$ ). The BFT larvae recorded significantly higher RNA/DNA ratios (ANCOVA, $\mathrm{F}_{1,232}=17.400$; $\mathrm{p}<0.001$ ) (Fig. 10).

\section{Spawning habitat conditions}

The hydrographic conditions in which BFT and ALB were sampled are clearly differentiated. The BFT larvae analysed were associated with Atlantic water masses ( $<37.00$ PSU), while the ALB larvae were associated with Mediterranean water masses (>37.5 PSU) (Fig. 11a). The temperature regime of these water masses showed surface temperature differences over $2^{\circ} \mathrm{C}$ (Fig. 11b).
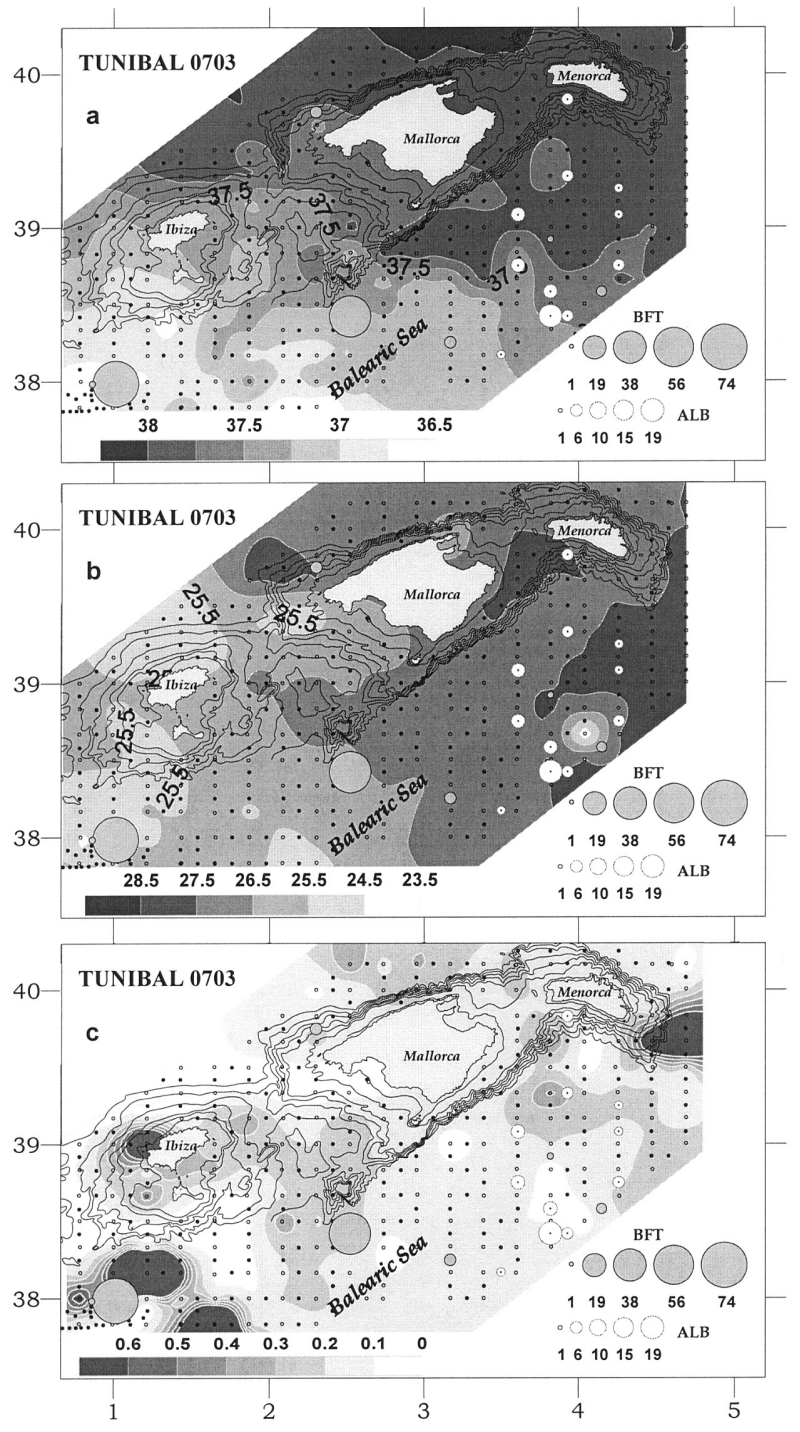

FIG. 11. - a) Salinity plots at $10 \mathrm{~m}$ depth; b) temperature plots at 10 $\mathrm{m}$ depth; c) distribution of PROT/DW ratios.

PROT/DW ratios of microzooplankton samples varied from a minimum value of 0.03 to a maximum value of 3.5. The PROT/DW ratio showed higher values in the water masses of Atlantic origin than those observed in Mediterranean water masses (Fig. 11c).

\section{DISCUSSION}

Growth studies in the early ontogenic stages are crucial to the understanding of early life history dynamics and the environmental forces that drive them. Recruitment variability is highly dependent on early larval and juvenile growth (Houde, 1987, 1989). 
Environmental conditions of a biotic and abiotic nature show a strong influence on the growth and condition of fish larvae. Changes of temperature can show strong effects on growth rates, and consequently on mortality (Chambers and Legget, 1987; Houde, 1989). Another source of mortality may be induced by starvation and predation (May, 1974; Bailey and Houde, 1989), which are inter-related since starvation leads to decreased growth rates (Buckley, 1984), and consequently greater vulnerability to predation (Folkvord and Hunter, 1986; Purcell et al., 1987).

Daily growth studies on tuna larvae are relatively scarce and field-oriented studies are even scarcer. The first BFT daily growth study was made by Brothers et al. (1983) on Thunnus thynnus field-collected larvae and juveniles, assuming daily increment formation. Different researchers have validated the daily periodicity of increment deposition on different tuna species. Itoh et al. (2000) and Foreman (1996) validated the daily periodicity of increment formation on BFT larvae. Validation of increment formations have also been confirmed on North Pacific albacore (T. alalunga) by Laurs et al. (1985), on yellowfin tuna (T. albacares) by Wexler et al. (2001), and on small tuna species (e.g. Euthynnus) by Radke (1983) and Wexler (1993).

In studies focusing on the analysis of nutritional status of tuna larvae, the existing techniques have tended towards histological methods, mainly focusing on histological characteristics and appearance of the digestive tract (Margulies, 1993; Kaji et al., 1996, 1999). However, nutritional condition studies by nucleic acid and protein content estimation are practically lacking in larval tuna.

In this survey, clear salinity signatures of Atlantic water masses at surface were observed south of Ibiza and its channel. The Atlantic intrusion extended midway towards the Mallorca channel and its southern area (Fig. 11a). Mediterranean water masses covered the northern coasts of Mallorca and the surrounding water masses of Menorca. A previous study carried out in the same area during the 2002 BFT spawning season showed that the PROT/DW was correlated with the nature of water masses (García et al., 2003a): it was negatively correlated with surface salinity and positively correlated with surface temperature.

Major abundances of BFT larvae were found in the southern part of the 2003 survey area, south of Ibiza and the Mallorca channel (García et al., 2003a). On the other hand, ALB larvae were mostly located in the southern part of the Mediterranean water masses (García, IEO unpublished data) and its transitional waters, indicating their acclimation to Mediterranean conditions.

The larval tuna species considered in this study show strong similarities in their morphological development at the analysed range of SL (see Fig. 3). Consequently, no significant differences were observed in PL and CH vs SL. With regard to the morphological development and growth of T. thynnus, the sampled population agrees with the description given by Miyashita et al. (2001) on the Pacific BFT.

The minimum sizes of the sampled BFT larvae $(2.8 \mathrm{~mm})$ correspond to pre-flexion larvae that were not newly hatched because no remnants of yolk presence were observed and their mouths were fully functional. This body size difference can be accounted for by larval shrinkage that was not estimated because no shrinkage factors for this species are available for the conservation agent used, liquid nitrogen.

The daily growth rate of BFT in this study $(0.35$ $\mathrm{mm} /$ day) is similar to those reported by Miyashita $e t$ al. (2001) and Jenkins and Davis (1990) for the Pacific BFT and the southern BFT (T. maccoyii) larvae, respectively.

BFT and ALB larvae showed SL vs age linear relationships and power functions with respect to DW vs age. For a given SL of BFT larvae, the size at age 10 would yield larvae of $6.3 \mathrm{~mm}$, in agreement with the study of Miyashita et al. (2001). These authors report that rapid growth in tuna occurs after 20 days $(9.34 \mathrm{~mm})$, when larvae begin metamorphosing into juveniles.

In this comparative study, no significant differences were observed in the SL and DW vs age between species. Likewise, otolith growth did not show significant differences between species. However, BFT larvae showed significantly higher DNA and RNA content vs age than ALB larvae, within the SL range common to both species $(<6$ $\mathrm{mm}$ ). With respect to the relationship of PROT content vs age, no significant differences between species were observed in the $<6 \mathrm{~mm}$ SL range.

The allometric relationship of DW vs SL within the same size range of the sampled population $(<6$ $\mathrm{mm}$ ) showed significantly higher DW in BFT larvae than in ALB larvae. The fact that DNA and RNA also show significantly higher content in BFT larvae 
is made evident by their greater somatic mass expressed as DW.

Nonetheless, PROT content showed no significant difference with respect to SL, yet when PROT content was referred to DW, ALB showed significantly higher PROT content within the DW range below $0.8 \mathrm{mg}$. The cellular rate of protein synthesis is a function of the number of ribosomes (Nomura et al., 1984), although their activity is highly influenced by temperature (Lied et al., 1983). ALB larvae showed that for the same amount of RNA, a greater amount of PROT was synthesised (see Fig. 9), which may be explained by the higher temperature regime at which ALB larvae were sampled.

The Mediterranean BFT spawners have been reported to be associated with frontal structures and anticyclonic gyres by Platonenko and de la Serna (1997). BFT larval distributions off the Balearic archipelago seem to sustain this hypothesis (García et al., 2003a,b). The area south of Ibiza where major BFT larval concentrations occurred was subject to the influence of two adjacent anticyclonic gyres (García et al., 2003a), made evident by surface temperature satellite imagery corresponding to the larval tuna sampling dates (Fig. 12). The convergence of neighbouring waters with different hydrographic characteristics tends to accumulate biotic and abiotic particles in the frontal region, thus enriching, concentrating and retaining phytoplankton and zooplankton in the frontal region (Bakun, 1996). García et al., (2003a) reported highest PROT/DW ratios and chlorophyll $a$ values in the southern region of the survey area.

Although bio-physical differences of the Atlantic and Mediterranean water masses include temperature differences $\left(2-3^{\circ} \mathrm{C}\right)$ and larval food availability, larval somatic growth of BFT and ALB larvae within their early ontogenic development, expressed as size and weight gain, and concurrently otolith growth, did not show significant differences between species.

With respect to the RNA/DNA ratios, BFT showed significantly greater values in relation to larval sizes (see Fig. 10). A negative relationship between the RNA/DNA ratios and temperature has been reported by several authors (Buckley, 1982; 1984; Goolish et al., 1984; Rámirez et al., 2004), in such a way that higher RNA/DNA estimates are found in fish acclimated to colder waters. A difference of around $2^{\circ} \mathrm{C}$ can account for significant effects on the RNA/DNA ratios (Buckley et al., 1999).

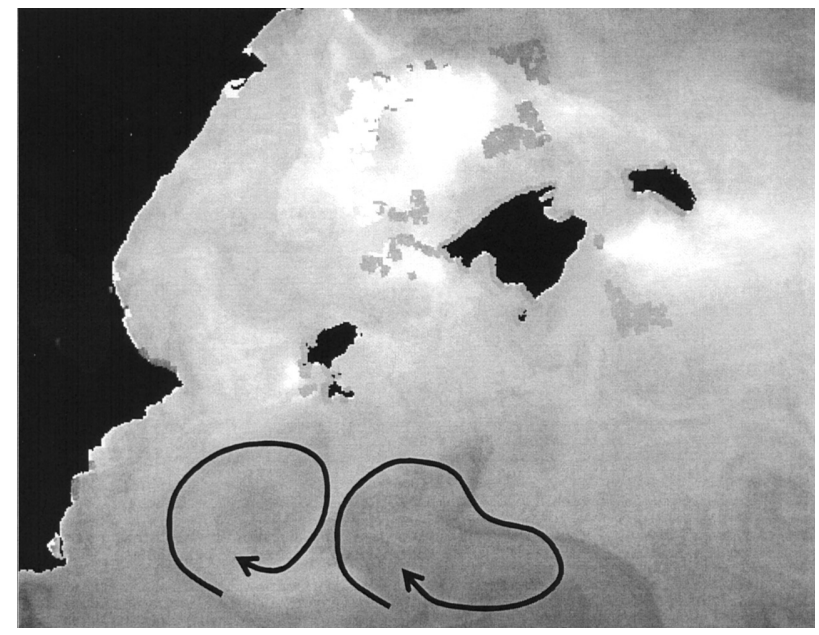

FIG. 12. - NOAA/AVHRR infrared sensor of SST satellite image downloaded from German Remote Sensing Centre web site corresponding to July 11, 2003, in which most bluefin larval samples off south Ibiza were collected. Arrows are superimposed on the adjacent anticyclonic gyres.

In conclusion, this study attempts to make evident the close relationships between BFT and ALB at the morphological level in their early life history, also shown in their growth trajectory as expressed by SL and DW with age. Despite this similarity, differences were manifested in the greater DNA and RNA content vs SL and DW, which may be responsible for the greater DW vs SL relationship in BFT. On the other hand, a lower PROT content was observed in BFT. Such differences may be caused by either the particular environmental differences in which each species was sampled or particular inherent biological differences between the two species.

\section{ACKNOWLEDGMENTS}

The authors would like to thank the Spanish Science and Technology Commission, which provided the funding for the TUNIBAL project (REN 2003-01176/MAR).

\section{REFERENCES}

Alemany, F. 1997. - Ictioplancton del Mar Balear. Ph.D. thesis, Univ. Islas Baleares, Palma de Mallorca.

Andersen, T. and E. Moksness. - 1988. Manual for reading daily increments by use of computer programme. Flddevigen Meld., 4: 1-37.

Anonymous. - 2003. Report of the 2002 Atlantic bluefin tuna stock assessment session. Col. Vol. Sci. Pap. ICCAT., (3): 710-937.

Bailey, K.M. and E.D. Houde. - 1989. Predation on eggs and larvae of marine fishes and the recruitment problem. Adv. Mar. Biol., 25: $1-83$.

Bakun, A. - 1996. Patterns in the Ocean: Ocean processes and 
Marine Population Dynamics. University of California Sea Grant Program, San Diego, California, USA in co-operation with Centro de Investigaciones Biologicas del Noroeste, La Paz, Mexico.

Belchier, M., C. Clemmesen, D. Cortés, T. Doan, A. Folkvord, A. García, A. Geffen, H. Høie, A. Johannessen, E. Moksness, H. de Pontual, T. Rámirez, D. Schnack, and B. Sveinsbo. - 2004. Recruitment studies: Manual on precision and accuracy of tools. ICES Tech. Mar. Environ. Sci., 33: 35 pp.

Berdalet, E and M. Estrada. - 1993. Relationships between nucleic acid concentrations and primary production in the Catalan Sea (Northwestern Mediterranean). Mar. Biol., 117(1): 163-170.

Brothers, E.B., E.C. Prince and D.W. Lee. - 1983. Age and growth of the young of the year bluefin tuna Thunnus thynnus, from otolith microstructure. NOAA Tech. Rep. NMFS., 8: 49-59.

Buckley, L.J. - 1982. Effects of temperature on growth and biochemical composition of larval winter flounder Pseudopleuronectes americanus. Mar. Ecol. Prog. Ser., 8: 181-186.

Buckley, L.J. - 1984. RNA-DNA ratio: an index of larval fish growth in the sea. Mar. Biol., 80: 291-298.

Buckley, L.J., E. Calderone and T.L. Ong. - 1999. RNA-DNA ratio and other nucleic acid-base indicators for growth and condition of marine fishes. Hydrobiology, 401: 265-277.

Carter, C.G., G.S. Seeto, A. Smart, S. Clarke and R.J. van Barneveld. - 1998. Correlates of growth in farmed juvenile southern bluefin tuna Thunnus maccoyii. Aquaculture, 161(14): 107-119.

Chambers, R.C. and W.C. Leggett. -1987. Size and age at metamorphosis in marine fishes: an analysis of laboratory-reared winter flounder (Pseudopleuronectes americanus) with a review of variation in other species. Can. J. Fish. Aquat. Sci., 44: 1936-1947

Clemmesen, C., R. Sanchez, and C. Wongtshowski. - 1997. A regional comparison of the nutritional condition of SW Atlantic anchovy larvae, Engraulis anchoita, based on RNA/DNA ratios. Arch. Fish. Mar. Res., 45(1): 17-43.

Chicharo, M.A. E. Esteves, A.M.P. Santos, A. dos Santos, A. Peliz, and P. Re. - 2003. Are sardine larvae caught off northern Portugal in winter starving? An approach examining nutritional conditions. Mar. Ecol. Prog. Ser., 257: 303-309.

Dicenta, A. - 1975. Identificación de algunos huevos y larvas de túnidos en el Mediterráneo. Bol. Inst. Esp. Oceanogr., 198:1-22.

Dicenta, A. - 1977. Zonas de puesta del atún (Thunnus thynnus) y otros tunidos del Mediterráneo Occidental y primer intento de evaluación del stock de reproductores de atun. Bol. Inst. Esp. Oceanogr., II: 313-319.

Folkvord, A. And J.R. Hunter. - 1986. Size specific vulnerability of northern anchovy (Engraulis mordax) larvae to predation by fishes. Fish. Bull. US., 84: 859-869.

Foreman, T. - 1996. Estimates of age and growth, and an assessment of ageing techniques, for northern bluefin tuna (Thипnи thynnus) in the Pacific Ocean. Bull. IATTC., 21(2): 74-123.

García, A., F. Alemany, P. Velez-Belchí, J.L. López Jurado, D. Cortés, J.M. de la Serna, C. González Pola, J.M. Rodríguez, J. Jansá and T. Ramírez. - 2003a. Characterization of the bluefin tuna spawning habitat off the Balearic Archipelago in relation to key hydrographic features and associated environmental conditions. ICCAT., SCRS/2003/76.

García, A., F. Alemany, P. Velez-Belchí, J.L. López Jurado, J.M. de la Serna, C. González Pola, J.M. Rodríguez and J. Jansá. 2003b. Bluefin tuna and associated species spawning grounds in the oceanographic scenario of the Balearic archipelago during June 2001. Col. Vol. Sci. Pap. ICCAT., 55(1): 138-148.

Goolish, E.M., M,G. Barron and I.R. Adelman. - 1984 Thermoacclimatory and response of nucleic acid and protein content of carp muscle tissue: influence of growth rate and relationship to glycine uptake by scales. Can. J. Zool., 62: 2164 2170.

Houde, E.D. - 1987. Fish early life dynamics and recruitment variability. Am. Fish. Soc. Symp., 2: 17-29.

Houde, E.D. - 1989. Subtleties and episodes in the early life of fishes. J. Fish. Biol., 35(Suppl A):29-38.

Itoh, T., Y. Shiina, S. Tsuji, E. Fuminori and T. Nobuhiro. - 2000 Otolith daily increment formation in laboratory reared larval and juvenile bluefin tuna Thunnus thynnus. Fish. Sci., 66(5): 834-839.

Jenkins, G.P. and T.L.O. Davis. - 1990. Age, growth rate, and growth trajectory determined from otolith microstructure of southern bluefin tuna Thunnus maccoyii larvae. Mar. Ecol. Prog. Ser., 63(1): 93-104.

Kaji, T., M. Tanaka, M. Oka, H. Takeuchi, S. Ohsumi, K. Teruya and N. Ishibashi. - 1996. Preliminary observations on development of Pacific bluefin tuna Thunnus thynnus (Scombridae) larvae reared in the laboratory, with special emphasis on the digestive system. Mar. Freshw. Res., 47: 261-269.

Kaji, T., M. Tanaka, Y. Takahashi, M. Oka, and J. Hirokawa. - 1999. Growth and morphological development of laboratory-reared yellowfin Thunnus albacares larvae and juveniles, with special emphasis on the digestive system. Fish. Sci., 65(5): 700-707.

La Mesa, M., M. Sinopoli and F. Andaloro. - 2005. Age and growth rate of juvenile bluefin tuna Thunnus thynnus from the Mediterranean Sea (Sicily, Italy). Sci. Mar. 69(2): 241-249.

Laurs, R.M., R. Nishimoto and J.A. Wetherall. - 1985. Frequency of increment formation on sagittae of North Pacific albacore (Thunnus alalunga). Can. J. Fish. Aquat. Sci., 42(9): 15521555.

Lied, E., G. Rosenlund, B. Lund and A. von der Decken. - 1983. Effects of starvation and re-feeding on in vitro protein synthesis in the white muscle of Atlantic cod (Gadus morhua). Comp. Biochem. Physiol., 76B: 777-781.

López-Jurado, J.L., J. García Lafuente, and N. Cano. - 1995. Hydrographic conditions of the Ibiza Channel during november 1990, March 1991, July 1992. Oceanol. Acta., 18(2): 235-243.

Lowry, O.H., N.J. Rosenbraugh, A.L. Farr and R.J. Randall. - 1951. Protein measurements with the Folin phenol reagent. J. Biol. Chem., 193: 256-275.

Margulies, D. - 1993. Assessment of the nutritional condition of larval and early juvenile tuna and Spanish mackerel (Pisces: Scombridae) in the Panama Bight. Mar. Biol., 115: 317-330.

May, R.C. - 1974. Larval mortality in marine fishes and critical period concept. In: J.H.S. Blaxter, (ed), The early life history of fish, pp 3-19. Springer Verlag, Berlin,.

Miyashita, S., Y. Sawada, T. Okada, O. Murata and H. Kumai. 2001. Morphological development and growth of laboratoryreared larval and juvenile Thunnus thynnus (Pisces: Scombridae). Fish. Bull., 99(4): 601-616.

Rao, N. I. and G. Krupanidhi. - 2001. Biochemical composition of zooplankton from the Andaman Sea. J. mar. biol. Ass. India, 43 (1-2): 49-56.

Rao, N.I. and R.R. Kumari. - 2002. Biochemical composition of zooplankton from Visakhapatnam harbour waters, east coast of India. Indian J. Mar. Sci., 31(2): 125-129.

Nomura, M., R. Gourse and G. Baughman. - 1984. Regulation of the synthesis of ribosomes and ribosomal components. A. Rev. Biochem., 53: 75-117.

Padoa, E. - 1956. Divisione Scombriformes. In: Uova, larve e stadi giovanili di Teleostei, pp. 548-572. Fauna Flora Golfo Napoli. Monografía 38.

Pinot, J. M., J. Tintoré, J. L. López-Jurado, M. L. Fernández de Puelles and J. Jansá - 1995. Three-dimensional circulation of a mesoscale eddy/front system and its biological implications. Oceanol. Acta., 18: 389-400.

Platonenko, S and J.M de La Serna - 1997. Observaciones Oceanográficas y Medioambientales en el Mediterráneo Occidental durante la Época de reproducción del Atún Rojo (Thunnus thynnus L. 1758). Col. Vol. Sci. Pap. ICCAT., 46(4): 496-501.

Purcell, J.E., T.D. Siferd and J.B. Marliave. - 1987. Vulnerability of larval herring (Clupea harengus pallasi) to capture by the jellyfish Aequorea victoria. Mar. Biol., 94: 157-162.

Radke, R.L. and B. Morales-Nin. - 1989. Mediterranean juvenile bluefin tuna: life history patterns. J. Fish. Biol., 35: 485-496.

Radke, R.L. - 1983. Otolith formation and increment deposition in laboratory-reared skipjack tuna, Euthynnus pelamis, larvae. NOAA Tech. Rep. NMFS., 8: 99-103.

Ramírez, T., D. Cortés, A. García and A. Carpena. - 2004. Seasonal variation of RNA/DNA ratios and growth rates of the Alborán Sea sardine larvae. Fish. Res., 68: 57-65.

Vélez-Belchí, P. and J. Tintoré. - 2001. Vertical velocities at an ocean front. Sci. Mar., 65: 301-304.

Wexler, J.B. - 1993. Validation of daily growth increments and estimation of growth rates of larval and early juvenile black skipjack tuna, Euthynnus lineatus, using otoliths. Bull. IATTC., 20: 400-413. 
78 • A. GARCÍA et al.

Wexler, J.B., D. Margulies, S. Masuma, N. Tezuka, K. Teruya, M. Oka, M. Kanematsu and H. Nikaido. - 2001. Age validation and growth of yellowfin tuna, Thunnus albacares, larvae reared in the laboratory. Bull. IATTC., 22(1): 52-71.
Received October 21, 2005. Accpeted February 22, 2006. Published online September 26, 2006. 